\title{
A new sociolinguistic taxonomy, 'cookbook', and immigrant communities
}

\author{
Yoshiyuki Asahi \\ National Institute for Japanese Language and Linguistics, \\ 10-2 Midori-cho, Tachikawa, Tokyo, 190-8561 Japan, \\ yasahi@ninjal.ac.jp
}

\begin{abstract}
Članek obravnava sociolingvistično taksonomijo, imenovano 'kuharska knjiga', ki je bila izvedena na podlagi njenega dobesednega pomena in njene rabe v laboratoriju. 'Kuharska knjiga' poskuša hkrati kategorizirati govorca na mikro- in družbo na makroravni. To nam omogoča podajanje natančnejšega sociolingvističnega opisa dane skupnosti. Za prikaz, kako lahko 'kuharska knjiga' pojasni jezikovne variacije, sta predstavljena primera dveh študij - študija novega mesta in študija diaspore.
\end{abstract}

This paper proposes a sociolinguistic taxonomy, called 'cookbook,' which aims to account for highly diverse communities. The definition of this 'cookbook' was derived based on its literal meaning, its usage in laboratory situations. 'Cookbook' aims to categorise both the speaker at a micro level and society at a macro level at the same time. This will enable us to render more accurate sociolinguistic descriptions in a given community. As examples, two case studies (new town study and diaspora study) are introduced to show how 'cookbook' can explain the attested linguistic variation.

Ključne besede: 'kuharska knjiga', sociolingvistična taksonomija, jezikovna variacija, japonščina, novo mesto, diaspora

Key words: 'cookbook', sociolinguistic taxonomy, language variation, Japanese, new town, diaspora

\section{Introduction}

Urbanisation and an increase in demographic movement have established a number of highly diverse societies around the world. Different from traditional methodology, which focuses on, so-called, NORM (Non-mobile, Old, 
Rural Men), urban dialectological and sociolinguistic surveys are expected to improve their research methodologies, which should pay enough attention to linguistic and sociolinguistic variation. It goes without saying that a number of urban dialectological studies were active in 1980s and early 1990s. However, as more attention was paid to struggle with language variation in the urban areas, sociolinguistic studies were faced with the limitation of their research methodology. As a result, since the late 1990s, less attention has been paid to the study of this particular facet of sociolinguistics although in reality there are plenty of potential research topics in urban societies.

This paper, under these situations, proposes a sociolinguistic taxonomy, called 'cookbook.' 'Cookbook' deals with the social meaning of social variables of a speaker, and also with the structure of society at the same time.

This paper consists of the four sections. First section offers an overview of the research methodology both in traditional dialectology and in urban dialectology/sociolinguistics, which is followed by the definition of 'cookbook' in the second section. The third section will examine two communities as case studies to measure to what extent this method can explain the linguistic phenomena attested there. The final section will serve as a summary of this paper.

\section{Research methods in traditional and urban dialectology/ sociolinguistics}

This section briefly reviews research methodologies in traditional and urban dialectology. Traditionally, one goal in dialectology is to construct the path of language change by obtaining data from a speaker who is thought to have the most traditional or oldest dialect system. A comparison of the data is then made with the previous findings. Dialectologists, based on their findings, examine the dynamism of language change. Therefore, a target of the dialectologist under this tradition, as mentioned earlier, is the speaker who is old, non-mobile, rural men.

Since Trudgill and Chambers (1980), the scope of dialectology became much wider. As indicated in the terminology, 'urban dialectology,' urban dialectological as well as sociolinguistic studies examine possible social variables; female speakers along with male speakers, young informants along with old informants; middle- and working-classes along with non-social-class division. New perspectives, at the same time, were proposed, including social networks, inter-ethnic situations, and so forth (Milroy 1980, Rickford 1999, etc.). All of this enabled us to construct 'sociolinguistic' approaches in the end.

Since the 1990s, however, this type of methodology seems to show its limitations in the sense that sociolinguistic studies especially in urban areas become difficult as their composition becomes further complicated. The reality is that most of the current sociolinguistic studies in urban areas only deal with some social variables (and their combinations). With a close look at those studies, some questions occur. In what way do sociolinguists deal with the language 
variation in highly diverse community? How do they assure accountability for the given phenomena? Existing research methodologies need improvements in order to observe the on-going linguistic changes in a number of societies with differing characters.

\section{2 'Cookbook' and its definition}

In order to struggle with these situations in contemporary urban society from sociolinguistic perspectives, this paper introduces a sociolinguistic taxonomy, called 'cookbook.' This 'cookbook' aims to define speakers and their society in order to render more accurate sociolinguistic descriptions of the target community. It follows that it can be posited as an attempt to establish a linguistic and social typology, or in other words, 'sociolinguistic typology.' This typology enables us to grasp and even estimate the sociolinguistic outcomes of the linguistic change in relation to the nature of the contact or any social constraints upon linguistic variation. In this way, 'cookbook,' is expected to make a contribution to sociolinguistic typology.

The term, 'cookbook,' is not a completely new term in science. In fact, it is used rather often in the natural sciences. Therefore, this section deals firstly with a literal meaning of the term 'cookbook' and secondly with a definition from the natural sciences.

\subsection{Literal meaning of 'cookbook'}

First and foremost, it is necessary to explain a literal meaning of 'cookbook,' in order to render its full definition as a sociolinguistic term. When considering a literal meaning of the term 'cookbook', most readers would assume that 'cookbook' simply refers to a collection of all the 'recipes' for certain kinds of dishes. When you decide to try a new meal, one of the things that you would do first is to consult a 'cookbook' in order to obtain information on what kinds of ingredients are required, and how much of each.

Let us take a look at one example here. You feel like cooking a Japanese dish, sushi. Unless you are native Japanese or have Japanese friends or know someone who has been in Japan, you need to get a 'cookbook' and read through its contents. Figure 1 is an example of the ingredients of California rolls from a Japanese cookbook.

Following the instructions in the cookbook, it is possible to cook sushi for any kind of situation. A 'cookbook' is therefore designed for anyone with any kind of background. 


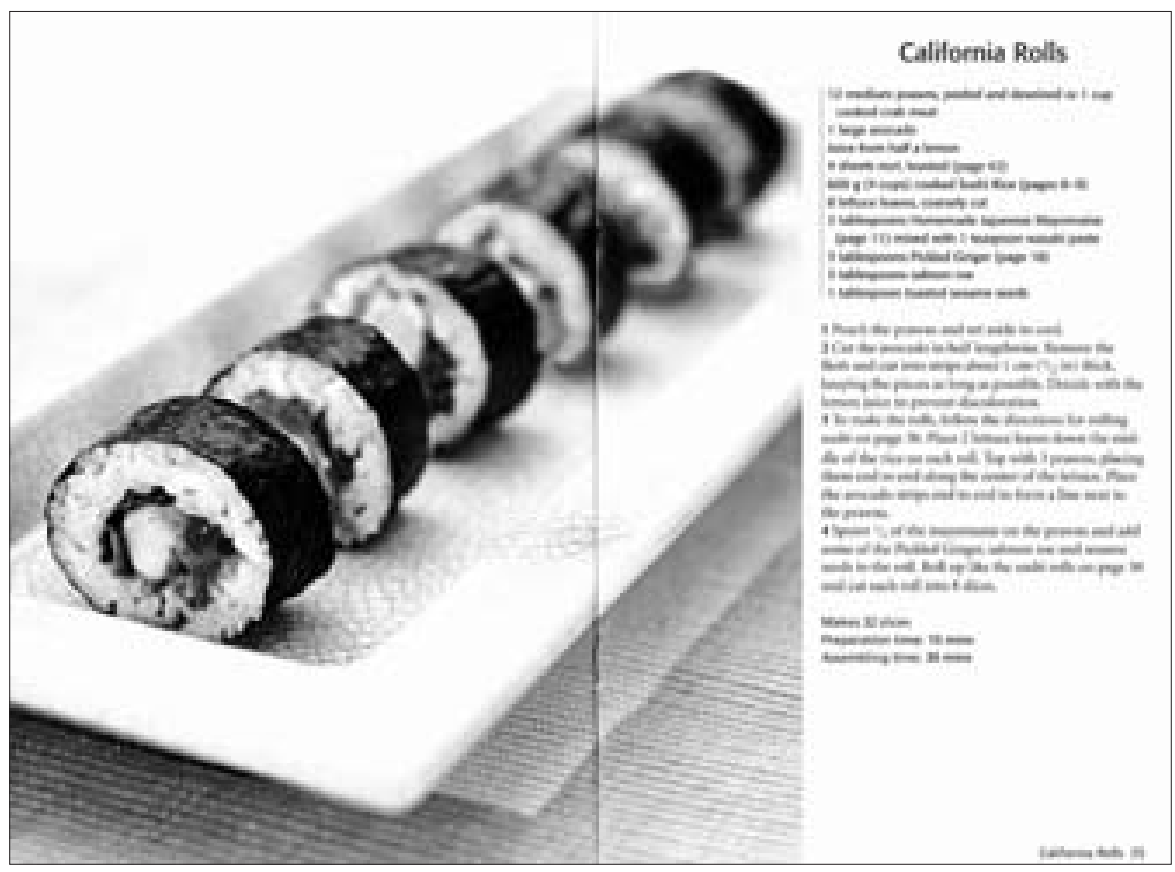

Figure 1 Ingredients of Japanese dish, sushi, in a 'cookbook' (Donald 2003, 34-35)

\section{2 'Cookbook' in the natural sciences}

Needless to say, a literal meaning of the term 'cookbook' is, as shown in the Figure 1, clear enough for anyone to understand. On the other hand, this term is also used in other fields, especially in laboratory situations in the natural sciences.

'Cookbook' in these situations refers to a set of information on all the 'trials and errors' of experiments to make new products. In laboratory situations, a number of lists would exist, each of which consists of the possible combinations of the ingredients/components with differing proportions. It also contains information on the outcomes of each combination through experimentation.

This type of experimentation can be better explained through examples from the products in our daily lives. One example is that of blended whisky. So-called 'blenders' conduct a series of experiments to measure the taste of the whisky by 'blending' some kinds of wheat. The individual performance of the blenders determines which types of wheat are blended to make a new brand. It is highly possible to assume that each blender has his or her own 'cookbook.'

In the same way, 'cookbooks' can be found in other laboratory situations as well. Specialists in medicine, computers, instruments, machinery, chemicals, brewing, radiology, and other fields gather their research activities and record them in their 'cookbooks.' 


\subsection{Definition of 'cookbook' as a sociolinguistic taxonomy}

Based upon what was mentioned in the previous sections, this section defines 'cookbook' in sociolinguistics. What is common in the usage of 'cookbook' in its literal meaning and as a term used at laboratory situations is that 'cookbook' is a list of ingredients for a dish or a composite of all 'ingredients' for the experiments. 'Cookbook' in sociolinguistics refers to the realisation of the speaker at a micro level and that of the society at a macro level. At the same time it refers to the interactions between the realisations of each level. In the same way as cookbook shows the components of the specific dishes or those of the experiments, 'cookbook' in a sociolinguistic sense categorises and defines both speaker and society. The rest of this section will explain what is meant by the setting speaker at micro level on the one hand and society at macro level on the other hand.

\subsection{1 'Cookbook' at a micro level: speaker}

At a micro level, cookbook can designate the realisation of a speaker as a basic unit of a society. Generally speaking, categorisations of the speaker in accordance with his/her social variables can be made in numerous ways. A composite of those social variables will create one speaker, which can be drawn in Figure 2.

Figure 2 consists of possible social variables which compose a speaker. The entity of the speaker itself includes all possible social variables whose social meanings and social assessments differ from one another.

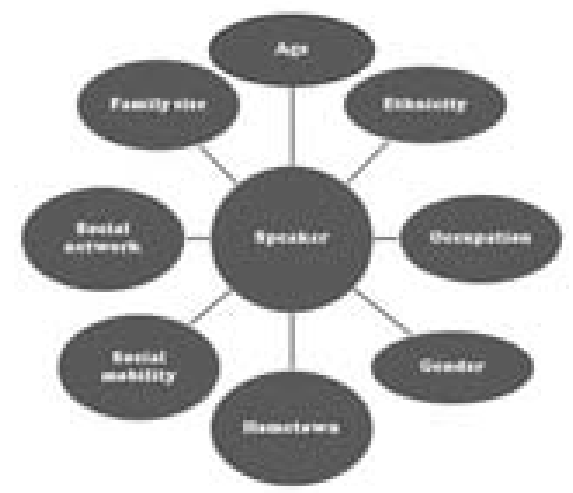

Figure 2 Composite of social variables in a speaker

Most sociolinguistic studies aim or focus on one or a few of a speaker's social variables. Needless to say, it indicates that they did not examine other variables of the speaker for their analyses. A possible explanation would be that sociolinguists treat social meanings of the social variables of all inform- 
ants in the same way, and do not recognise the inter-personal differences in the meaning of each social variable. Another possible explanation would be that sociolinguists simply believe that they should only raise some 'basic' social variables such as age, sex, that totally misses the important fact that speaker's entity is realised with a combination of social variables whose social value differs in varying extents from one person to another.

'Cookbook', on the other hand, treats all possible social variables, and combines them for the analyses. The reason is clear; their social meanings would have a lot to do with the explanation of linguistic variation. When studying language variation within society, especially in urban or migrants' societies, this importance becomes vital.

\subsection{2 'Cookbook' at a macro level: society}

Along with the designation of the speaker at a micro level, 'cookbook' focuses on the society at a macro level. Different from the 'speaker' as in the previous section, the categorisation of the society in sociolinguistics has not yet been fully made.

Most studies, in reality, address one society, and categorise it into a certain type of society, such as large city, local city, town, village, and so on. Even if they look into several societies as their fields, their categorisation is not well-organised. It is rather normal in sociolinguistic study or dialectological study that two societies are raised as fields of study. The problem is that most sociolinguistic studies regard the social structure of the society as the same in any iteration of the society.

The structure of the society itself can be described in Figure 3. As shown in Figure 3, a number of factors do exist as components of the society. The social meanings of each factor show differences in their nature.

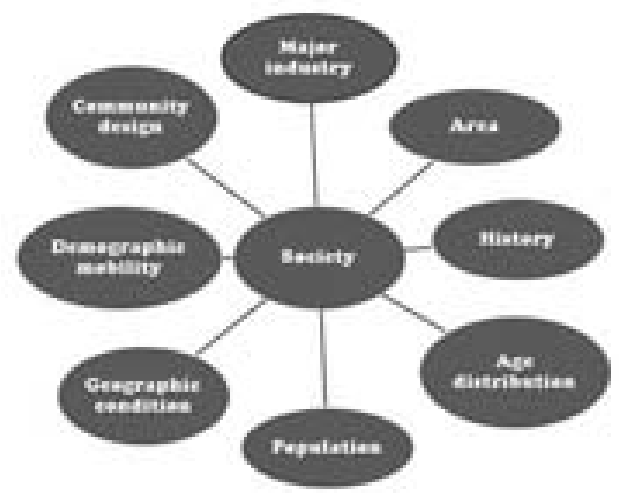

Figure 3 Composite of factors in the structure of society 
What should be emphasized here is that the social meaning of each component does differ from each other. Furthermore, each society has its own components, which make it different from other societies. In other words, if sociolinguists attempt to make comparisons with more than one community, they need to know more detailed knowledge of the differences in the components.

In order to struggle with these situations, 'cookbook' does aim to show much more accurate description and categorisation of the societies. This would enable us to decide the social meanings of the difference between two communities.

\section{Scope of the 'cookbook'}

This section, based on the definition made in the previous sections, attempts to show what 'cookbook' in a sociolinguistic sense can do with the speaker, society, and linguistic behaviour. As stated earlier, the specific content of the cookbook will be illustrated to show how the cookbook is compiled of a list of social variable for both the individual speaker and the society. Cases studies in this section are (1) New Town Study (Asahi 2006a, etc.) and (2) diaspora study (Asahi 2006b, 2009a, 2009b, forthcoming, etc.). This section first illustrates categorisations based on the 'cookbook' for the society. Second, this section categorises and looks into the speaker in each society with relevant linguistic data.

\subsection{Categorisation of the communities}

What 'cookbook' should first do at the beginning of the study is classify the community based on the peculiarities of its social components. This section renders an overview of how this categorisation is created with two types of communities.

Table 1 is a summary of this categorisation of the two studies. In New Town Study, two neighbouring societies were studied. The social components differ in great extent from each other. One major difference is that Seishin New Town is a new, highly mobile, urban community about 30 years old, whilst Hazetani-cho is an old, traditional, non-mobile, agriculture-based, and rural community more than 100 years old.

Diaspora study, on the other hand, addresses one society, which arose at the beginning of the twentieth century. Sakhalin Island is more diverse in a sociolinguistic sense since this island has received a number of migrants of numerous linguistic backgrounds.

Table 1 describe the features of the two communities. What is more, the same scale would provide us with an opportunity to decide to what extent each community shares its social components. 
Table 1 Categories of the two communities

\begin{tabular}{|c|c|c|c|}
\hline \multirow{2}{*}{} & \multicolumn{2}{|c|}{ (1) New Town Study } & (2) Diaspora Study \\
\cline { 2 - 4 } & Seishin New Town & Hazetani cho & Sakhalin \\
\hline Population & c.60,000 & c.2,000 & c.2,000 \\
\hline Major Industry & $\begin{array}{c}\text { Service industry, } \\
\text { Specialist, Teachers }\end{array}$ & Agriculture & $\begin{array}{c}\text { Agriculture, } \\
\text { Manufactory, Service } \\
\text { Industry }\end{array}$ \\
\hline History & 1980 -present & 1900 -present & 1905 -present \\
\hline Social Mobility & High & Low & Low \\
\hline Community design & Yes & No & Yes \\
\hline Age Distribution & $0-50$ & $0-80$ & $50-80$ \\
\hline Major Dialect & Western Japan & Kobe dialect & Northern Japan \\
\hline
\end{tabular}

\subsection{Categorisation of the speaker}

What 'cookbook' should do is classify the speakers in the same way as it did with the society. Classification of communication enables sociolinguists to know what kind of the community that they are going to work with. Based on this categorisation, 'cookbook' makes further categories based on the speakers. Table 2 is a summary of the classification of the speakers.

Table 2 Classification of the speakers in two studies

\begin{tabular}{|c|c|c|c|c|c|c|c|c|c|}
\hline & \multicolumn{6}{|c|}{ (1) New Town Study } & \multirow{2}{*}{\multicolumn{3}{|c|}{$\frac{\text { (2) Diaspora Study }}{\text { Sakhalin }}$}} \\
\hline & \multicolumn{3}{|c|}{ Seishin New Town } & \multicolumn{3}{|c|}{ Hazetani-cho } & & & \\
\hline & $\begin{array}{c}\text { Speaker } \\
\text { I }\end{array}$ & $\begin{array}{c}\text { Speaker } \\
\text { II }\end{array}$ & $\begin{array}{c}\text { Speaker } \\
\text { III }\end{array}$ & $\begin{array}{c}\text { Speaker } \\
\text { I }\end{array}$ & $\begin{array}{c}\text { Speaker } \\
\text { II }\end{array}$ & $\begin{array}{c}\text { Speaker } \\
\text { III }\end{array}$ & $\begin{array}{c}\text { Speaker } \\
\text { I }\end{array}$ & $\begin{array}{l}\text { Speaker } \\
\text { II }\end{array}$ & $\begin{array}{c}\text { Speaker } \\
\text { III }\end{array}$ \\
\hline Age & 51 & 50 & 44 & 40 & 38 & 39 & 83 & 83 & 77 \\
\hline Gender & Female & Female & Female & Female & Female & Female & Male & Male & Female \\
\hline Ethniciy & Japanese & Japanese & Japanese & Japanese & Japanese & Japanese & Japanese & Japanese & Uilta \\
\hline Occupation & $\begin{array}{l}\text { House- } \\
\text { wife }\end{array}$ & $\begin{array}{l}\text { House- } \\
\text { wife }\end{array}$ & $\begin{array}{l}\text { House- } \\
\text { wife }\end{array}$ & $\begin{array}{l}\text { House- } \\
\text { wife }\end{array}$ & $\begin{array}{l}\text { House- } \\
\text { wife }\end{array}$ & $\begin{array}{l}\text { House- } \\
\text { wife }\end{array}$ & Retired & Retired & Retired \\
\hline Hometown & Kobe & Kobe & Kobe & $\begin{array}{l}\text { Hazetani- } \\
\text { cho }\end{array}$ & $\begin{array}{l}\text { Hazetani- } \\
\text { cho }\end{array}$ & $\begin{array}{l}\text { Hazetani- } \\
\text { cho }\end{array}$ & Shisuka & Shisuka & Shisuka \\
\hline $\begin{array}{c}\text { Social } \\
\text { Mobility }\end{array}$ & Low & High & Low & Low & Low & Low & Low & Low & Low \\
\hline
\end{tabular}

Breakdown of the speakers in two societies are shown in Table 2. This table seems not to be so different from the breakdowns in other studies. However, what should be emphasised here is the COMBINATION with the classification of the society. 
Table 2 shows that, in New Town Study, the sociolinguistic backgrounds of the speakers in two communities are almost the same although the type of the community differs from each other. Diaspora study also shows that the sociolinguistic history of each speaker can be traced when the linguistic analyses are to be conducted.

The next section will illustrate to what extent this combination can explain the differences observed in linguistic behaviour.

\subsection{Cookbook and linguistic behaviour}

This section gives an example from the Seishin New Town Study to show that the 'cookbook's' combination of speaker and society would help us understand the linguistic variation observed in the study.

In Seishin New Town Study, spontaneous speeches were collected from New Town residents on the one hand, and from Hazetani-cho residents on the other. According to the classification of the community, the two communities were different in nature; New town as an urban, community and Hazetani-cho as a rural community. Speaker's classification, however, did not show much difference.

The linguistic variable examined here is verb negation in Japanese. Generally speaking, in standard Japanese, -nai/-nakatta (for non-past and past forms respectively) are used by affixing them to the verb stems.

(1) aruk-anai

kak-anai walk-NEG write-NEG

(2) aruk-anaka-tta kak-ana-tta walk-NEG-PST write-NEG-PST

In Kobe dialect (or Hazetani-cho dialect), a different affix would be used: -n/-nkatta, -hen/-henkatta (for non-past and past forms respectively), and nanda (for a past form).

(3) aruk-an/-ahen walk-NEG

(4) aruk-anka-tta/-ahenka-tta/-ananda walk-NEG-PST kak-an/-ahen write-NEG

kak-anka-tta/-ahenka-tta/-henanda write-NEG-PST

The number of the occurrences in spontaneous speech was counted for each variant. The percentage of each variant was calculated to make comparisons. Figure 4 is a result of the use of this verb negation.

Figure 4 shows that the use of the variants in the two communities is different from each other. Although their dialectal backgrounds show such a great similarity, the choice of the variant and its amount of the use differs greatly in Seishin New Town and Hazetani-cho. 


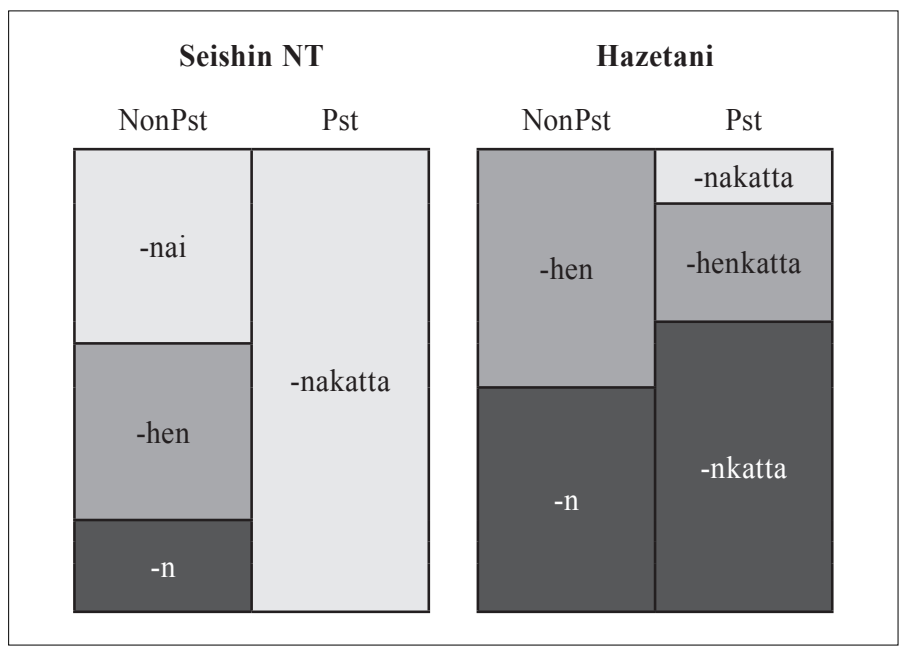

Figure 4 Percentage of each variant in the verb negation

This kind of difference can be attributed to the difference in the nature of the community. By examining this data with 'cookbook', the differences obtained from the data shown in Figure 4 can be designated to the difference of the social component of the society. New Town is an 'urban' community with a number of migrants from other places of Japan. Hazetani-cho is a 'rural' and 'traditional' community with a simple social structure.

\section{Conclusions}

This paper looked into a literal meaning of the term 'cookbook,' and a meaning used in laboratory situations. Based on these findings, this paper made a definition of the term 'cookbook' as a sociolinguistic taxonomy. Two speech societies and nine speakers were presented as an example of cookbook categorisations. Linguistic analysis of the New Town study showed that careful categorisation based on the 'cookbook' can determine which social component contributed to the different linguistic behaviours.

There are a number of things to be pursued. Other categorisations of both communities and speakers would be needed in order to stress the importance of this method. In fact, it is necessary to keep tracking of various combinations of the social variables so as to draw an overview of the sociolinguistic variation. Secondly, cross-social categorisations are also expected; social structure is more or less culture-specific. In this sense, attempts should be made to determine in what way sociolinguists need to upgrade the cookbook when societies of specific countries are to be studied. 


\section{REFERENCES}

Yoshiyuki ASAHI, 2006a: Contact-induced language change in an urban community: the case of Japanese new town. Japanische Beitraege zu Kultur und Sprache. Studia Iaponica Wolfgango Viereck emerito oblata. Munich: Lincom. 97-110.

- -, 2006b: On the remnant of Japanese in Sakhalin Island. $21^{\text {st }}$ century COE program Interface Humanities Research Activities, Toyonaka: Osaka University.

- -, 2009a: 'Linguistic features of a Japanese Variety in a Japanese Diaspora: Evidence from a Sakhalin Japanese speaker of Uilta.' Linguistic world of Sakhalin. Sapporo: Hokkaido University Press, 27-40.

- -, 2009b: 'Cookbook method' and koine-formation: a case of the Karafuto dialect in Sakhalin.' Dialectologia, 2, 1-21.

- -, Forthcoming: 'On the relationship of two Japanese regional koines: Evidence from Karafuto and Hokkaido Japanese.' Proceedings of METHODS XIII, Thirteenth International conference on Methods in dialectology. University of Bamberg.

Susie DONALD, 2003: Quick \& easy sushi and sashimi. Singapore: Periplus Editions.

Lesley MILROY, 1980: Language and social network. Oxford: Basil Blackwell.

John RICKFORD, 1999: African American Vernacular English: Features and Use, Evolution, and Educational Implications. Oxford: Blackwell.

Peter TRUDGILL and Jack K. CHAMBERS, 1980: Dialectology. Cambridge: CUP.

\section{NOVA SOCIOLINGVISTIČNA TAKSONOMIJA - 'KUHARSKA KNJIGA' IN EMIGRANTSKE SKUPNOSTI}

'Kuharska knjiga' pomensko združuje seznam sestavin za različne jedi; izvorno se uporablja v kuharski terminologiji, preneseno pa tudi v laboratorijih, in sicer za preverjanje številnih kombinacij elementov za merjenje stopnje njihovega učinkovanja - 'kuharska knjiga' se $\mathrm{v}$ tem pomenu nanaša na zbirko informacij o »poskusih in napakah« pri izvedbi eksperimenta.

Razprava poudarja prednosti uporabe »metode kuharske knjige« v dialektologiji, še zlasti pri študijah dialektološke transplantacije. Razprava izhaja iz dveh narečij, to sta karafutsko in hokaidsko narečje. Karafutsko narečje je nastalo na ruskem otoku Sahalinu, kamor so bila »presajena« številna japonska narečja, predvsem iz Hokkaida. Hokaidsko narečje je nastalo z narečnim stikom z emigranti celinske Japonske, zato lahko karafutsko narečje imenujemo »koine iz koine«. Razprava se osredotoča na naglasni vzorec kot spremenljivko - ugotavlja, kako metodologija 'kuharske knjige' pojasnjuje jezikovno spremembo v dveh narečjih. 